\title{
Trichurid Nematodes in Ring-necked Pheasants from Backyard Flocks of the State of Rio de Janeiro, Brazil: Frequency and Pathology
}

\author{
Roberto Magalhães Pinto/ ${ }^{+++}$, Rogério Tortelly*, Rodrigo Caldas Menezes, \\ Delir Corrêa Gomes/ ${ }^{++}$
}

\begin{abstract}
Laboratório de Helmintos Parasitos de Vertebrados, Departamento de Helmintologia, Instituto Oswaldo Cruz-Fiocruz, Av. Brasil 43565, 21040-900 Rio de Janeiro, RJ, Brasil *Departamento de Patologia, Faculdade de Veterinária, Universidade Federal Fluminense, Niterói, RJ, Brasil
\end{abstract}

The present investigation is related to the frequency of infection and to the gross and microscopic lesions associated to the presence of trichurid worms in 50 ring-necked pheasants (Phasianus colchicus) from backyard flocks in the state of Rio de Janeiro, Brazil. In the investigated birds, the overall infection rate was of 74\%, with the presence of Eucoleus perforans with $72 \%$ of prevalence and 21.2 of mean intensity, in the esophageal and crop mucosa and rarely in the junction of the proventriculus and esophagus, E. annulatus with $2 \%$ and 3 in the crop mucosa, Capillaria phasianina, with $12 \%$ and 4.3 in the cecum and small intestine and Baruscapillaria obsignata, for the first time referred in this host, with $2 \%$ and 1 in the small intestine. Clinical signs were absent. The gross lesions observed in the crop and esophagus of 14 (38.9\%) pheasants parasitized with E. perforans were thickening, small nodules, congestion, and petechial haemorrhages in the mucosa. These birds presented a mean infection of 37.5 and a range of infection of 10-82. The microscopic lesions revealed chronic esophagitis with diffuse inflammatory process in the lamina propria characterized mostly by a mononuclear cell infiltrate and also with the presence of granulocytes. In the case of the parasitism of pheasants with C. phasianina, the gross lesions were absent; microscopic lesions were characterized by chronic typhlitis with mononuclear infiltrate. Gross and microscopic lesions were absent in the pheasants parasitized with $\mathrm{E}$. annulatus and $\mathrm{B}$. obsignata.

Key words: trichurid - nematodes - Phasianus colchicus - pathology - Brazil

The ring-necked pheasant (Phasianus colchicus L., 1758 ) is the most known and worldwide spread species either in wild environments or in backyard flocks for trading. Thus, the ring-necked pheasant is of great economic importance, considering that it is an edible bird and also utilized for game and ornamental purposes (Silva 1987).

In Brazil, this pheasant species is most reserved for food; the meat is highly valuated in supermarket facilities (Silva 1987). Generally, birds are pen-raised with access to the ground and thus exposed to helminth infections (Permin et al. 1999, Ruff 1999).

Among the most frequent helminth parasites of the pheasant and other domestic Galliformes hosts, trichurid worms are of relevance (Bickford \& Gaafar 1966, Kellogg \& Prestwood 1968, Ruff 1999, Menezes et al. 2001). Worldwide reported species of this group, parasitizing ringnecked pheasants and according to the classification proposed by Moravec (1982), are: Eucoleus perforans (Kotlán \& Orosz, 1931), E. annulatus (Molin, 1858), E. contortus (Creplin, 1839), Capillaria uropapillata Freitas \& Almeida, 1935 parasitizing the crop and esophagus mucosa,

\footnotetext{
$\overline{{ }^{+} \text {Corresponding author. Fax: }}+55-21-2598.4363$. E-mail: rmpinto@ioc.fiocruz.br

++ Research fellow CNPq

Received 16 April 2004

Accepted 9 September 2004
}

Aonchotheca caudinflata (Molin, 1858), Baruscapillaria obsignata (Madsen, 1945) infecting the small intestine, C. phasianina Kotlán, 1940 in the small intestine and cecum and C. collaris (Linstow, 1873) in the cecum (Freitas \& Almeida 1935, 1936, Reis \& Nobrega 1938, Madsen 1941, 1951, Freitas et al. 1959, Clapham 1961, Bickford \& Gaafar 1966, Kellogg \& Prestwood 1968, Barus \& Sergejeva 1989a, b).

Costa et al. (1986) and Vicente et al. (1995) listed four species of trichurid worms parasitizing Brazilian ringnecked pheasants: C. phasianina, C. uropapillata, E. annulatus, and E. perforans.

They are highly pathogenic for domestic galliforms, mainly the species $E$. perforans, E. annulatus, and $A$. caudinflata that in the ring-necked pheasants cause apathy, emaciation, diarrhoea and death (Cram 1936, Reis \& Nobrega 1938, Bickford \& Gaafar 1966, Hurst et al. 1979, Mathey \& Gutter 1979, De Rosa \& Shivaprasad 1999).

In despite of the economic importance of the ringnecked pheasants and the loss this group of helminths provokes, there are few data on the pathology related to the burdens of trichurid worms in this host, except for the studies of Cram (1936), Reis and Nobrega (1938) and Bickford and Gaafar (1966) and the reports on the prevalence and mean intensity of infection (Madsen 1941, Clapham 1961, Kellogg \& Prestwood 1968).

Moreover, there is evidence that parasitism by helminths seems to increase the vulnerability of released pheasants to predators; nevertheless, the way parasites affect host vulnerability remains unclear (Millán et al. 2002). 
The present investigation is related to the frequency of infection and to the gross and microscopic lesions associated to the presence of trichurid worms in ring-necked pheasants from backyard flocks in the state of Rio de Janeiro, Brazil.

\section{MATERIALS AND METHODS}

Fifty adult specimens of ring-necked pheasants (Phasianus colchicus L., 1758), 25 males, 25 females, weigh 200-1750 g from backyard flocks of 11 localities of the state of Rio de Janeiro, Brazil, were investigated. Localities and numbers of examined hosts are respectively: Niterói ( $22^{\circ} 53^{\prime}$ S $\left.-43^{\circ} 06^{\prime} \mathrm{W}\right)$ : 9; Rio de Janeiro (22 $2^{\circ} 54^{\prime}$ 'S$\left.43^{\circ} 12^{\prime} \mathrm{W}\right)$ : 8; Tanguá (22 $\left.2^{\circ} 73^{\prime} \mathrm{S}-42^{\circ} 71^{\prime} \mathrm{W}\right)$ : 9; São Francisco do Itabapoana $\left(21^{\circ} 28^{\prime} S-41^{\circ} 08^{\prime} \mathrm{W}\right)$ : 8; Santo Antônio de

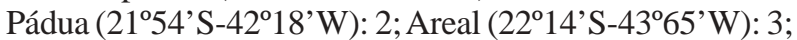
Petrópolis ( $\left.22^{\circ} 30^{\prime} \mathrm{S}-43^{\circ} 10^{\prime} \mathrm{W}\right)$ : 2 ; São José do Vale do Rio Preto ( $\left.22^{\circ} 09^{\prime} \mathrm{S}-42^{\circ} 55^{\prime} \mathrm{W}\right)$ : 2 ; Rio Bonito ( $22^{\circ} 43^{\prime} \mathrm{S}-42^{\circ} 37^{\prime} \mathrm{W}$ ): 4; Engenheiro Paulo de Frontin (22 $32^{\prime}$ S- $\left.43^{\circ} 40^{\prime} \mathrm{W}\right)$ : 2; Laje do Muriaé $\left(21^{\circ} 12^{\prime} \mathrm{S}-42^{\circ} 07^{\prime} \mathrm{W}\right)$ : 1 . After individual clinical evaluation birds were killed and submitted to necropsy, according to the technique of Zander et al. (1997).

All organs of the digestive tract were removed and opened with the aid of a scissor, in separated Petri dishes containing $0.85 \% \mathrm{NaCl}$ solution. The mucosas were scraped with microscopic slides and after, the nematodes were collected with the aid of thin brushes, (no. 00), rinsed in the same solution, fixed with hot A.F.A (alcohol $70^{\circ} \mathrm{GL}$, $93 \mathrm{ml}$; formaldehyde, $5 \mathrm{ml}$; acetic acid, $2 \mathrm{ml}$ ) and counted under a stereoscope microscope. Values referring to prevalence, mean intensity, mean abundance and range of infection are in accordance with Bush et al. (1997).

Nematodes were clarified in acetic acid and phenol, and some were stained with alcoholic chloride Langeron's carmine by the regressive process, according to Amato (1985) and identified with basis on Vicente et al. (1995) and Barus and Sergejeva (1989a, b). Some especimens were preserved in Canada balsam and deposited in the Helminthological Collection of the Oswaldo Cruz Institute (CHIOC) no. 36327 a-c, 36337, 36338 a-b, 36339, 36340, $36341,36342,36343,36344,36345,36346,36347$ a, 36350 a-b, 36351 a-d, 36352 (whole mounts); slides 36347 b, 36348, $36349,36350 \mathrm{c}$ refer to histological sections. Fragments of the parasitized organs were removed and immediately fixed in $10 \%$ formalin. The material was then routinely processed (Behmer et al. 1976) for parafin embedding. Five micrometers thick sections were stained with hematoxylin and eosin (HE).

The development of this research has been authorized by the Committee of Ethics for the Use of Animals (CEUA/Fiocruz) no. P0095-01.

\section{RESULTS}

In the investigated birds, the prevalence of parasitism with trichurid nematodes was of $74 \%$, with the presence of E. perforans in the esophageal and crop mucosa and rarely in the junction of the proventriculus and esophagus (Fig. 1), E. annulatus in the crop mucosa, $C$. phasianina in the cecum and small intestine and $B$. obsignata in the small intestine. Data on prevalence, mean intensity, mean abundance and range of infection are presented in Table I. The nematodes were recovered from hosts obtained in ten out of the eleven investigated localities (Table II). Parasitized birds did not present with clinical signs.

The gross lesions observed in the crop and esophagus of 14 (38.9\%) pheasants parasitized with E. perforans were thickening, small nodules, congestion and petechial haemorrhages in the mucosa. These birds presented a mean infection of 37.5 and a range of infection of 10-82. The microscopic lesions revealed chronic esophagitis with diffuse inflammatory process in the lamina propria characterized mostly by a mononuclear cell infiltrate and also with the presence of granulocytes and congestion (Fig. 2). In some areas of the crop mucosa and esophagus the inflammatory reaction was absent, in despite of the presence of the inserted parasites (Fig. 3). Several sections of specimens of $E$. perforans, deeply located in the squamous stratified epithelium of the crop and esophagus together with bioperculate acidophilic eggs (Figs 2, 3), were observed. In some regions of the epithelium there were tunnels projecting towards the lumen of the organ and

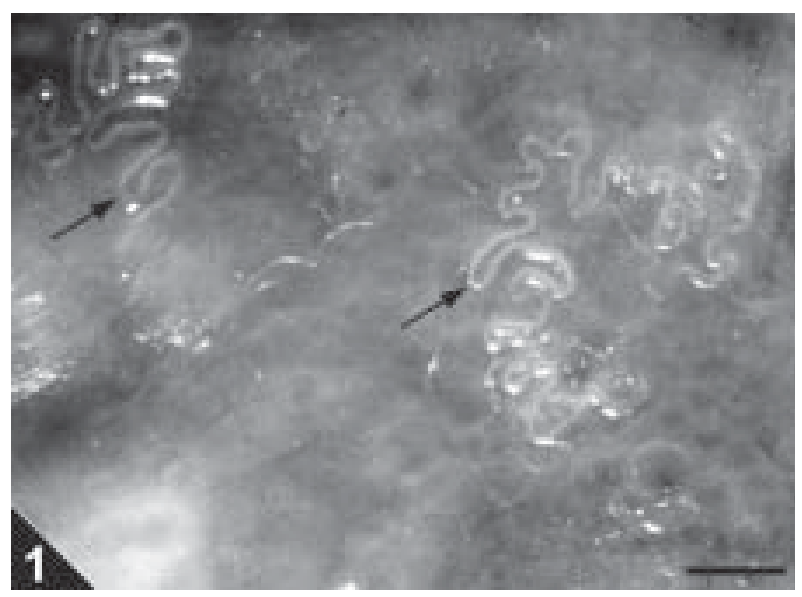

Fig. 1: crop of Phasianus colchicus parasitized with Eucoleus perforans (arrow) showing adult specimens embedded in the mucosa. Bar $=0.5 \mathrm{~mm}$

TABLE I

Prevalence, mean intensity, mean abundance, and range of infection of trichurid nematodes parasitizing ring-necked pheasants from backyard flocks in the state of Rio de Janeiro, Brazil

\begin{tabular}{lcccc}
\hline Helminths & Prevalence $(\%)$ & Mean intensity & Mean abundance & Range of infection \\
\hline Eucoleus perforans & 72 & 21.2 & 15.30 & $1-82$ \\
Eucoleus annulatus & 2 & 3.0 & 0.06 & 3 \\
Capillaria phasianina & 12 & 4.3 & 0.52 & $1-15$ \\
Baruscapilaria obsignata & 2 & 1.0 & 0.02 & 1 \\
\hline
\end{tabular}


TABLE II

Data on trichurid nematodes parasitizing ring-necked pheasants from backyard flocks in the state of Rio de Janeiro, Brazil

\begin{tabular}{|c|c|c|c|c|}
\hline \multirow[b]{2}{*}{ Localities } & \multicolumn{4}{|c|}{ Prevalence $(\%)$ / Mean intensity / Range of infection } \\
\hline & Eucoleus perforans & Eucoleus annulatus & Capillaria phasianina & Baruscapillaria obsignata \\
\hline Niterói & $100 / 20.7 / 1-61$ & $0 / 0 / 0$ & $0 / 0 / 0$ & $11.1 / 1 / 1$ \\
\hline Rio de Janeiro & $75 / 10.0 / 1-22$ & $0 / 0 / 0$ & $37.5 / 7.3 / 1-15$ & $0 / 0 / 0$ \\
\hline Tanguá & $0 / 0 / 0$ & $0 / 0 / 0$ & $0 / 0 / 0$ & $0 / 0 / 0$ \\
\hline São Franscisco do Itabapoana & $75 / 18.0 / 3-33$ & $12.5 / 3 / 3$ & $0 / 0 / 0$ & $0 / 0 / 0$ \\
\hline Santo Antônio de Pádua & $100 / 42.5 / 3-82$ & $0 / 0 / 0$ & $0 / 0 / 0$ & $0 / 0 / 0$ \\
\hline Areal & $100 / 21.7 / 1-47$ & $0 / 0 / 0$ & $0 / 0 / 0$ & $0 / 0 / 0$ \\
\hline Petrópolis & $100 / 21.0 / 8-34$ & $0 / 0 / 0$ & $0 / 0 / 0$ & $0 / 0 / 0$ \\
\hline São José do Vale do Rio Preto & $50 / 72.0 / 72$ & $0 / 0 / 0$ & $0 / 0 / 0$ & $0 / 0 / 0$ \\
\hline Rio Bonito & $100 / 21.0 / 8-35$ & $0 / 0 / 0$ & $0 / 0 / 0$ & $0 / 0 / 0$ \\
\hline Engenheiro Paulo de Frontin & $100 / 39.0 / 8-70$ & $0 / 0 / 0$ & $50 / 1.0 / 1$ & $0 / 0 / 0$ \\
\hline Laje do Muriaé & $100 / 26.0 / 26$ & $0 / 0 / 0$ & $100 / 1.0 / 1$ & $0 / 0 / 0$ \\
\hline
\end{tabular}

frequently containing several eggs (Fig. 4). In two parasitized birds cellular debris were present in the interior of these tunnels that were lined with acidophilic material, around either the parasites or the eggs (Fig. 5). In one of the birds, distension of the mucosal glands of the esophagus was observed. In the pheasant with the highest parasite burden, an area of thickening and papillary transformation of the esophagus mucosa was observed (Fig. 6).

In the case of the parasitism of pheasants with $C$. phasianina, the gross lesions were absent; microscopic lesions were characterized by chronic typhlitis with mononuclear infiltrate, sections of parasites partially inserted in the cecal mucosa, together with acidophylic bioperculate eggs in the cecal lumen (Fig. 7).

Gross and microscopic lesions were absent in the ringnecked pheasants parasitized with $E$. annulatus and $B$. obsignata.

\section{DISCUSSION}

The high prevalence of trichurid worms presently observed was also reported by Menezes et al. (2001) in guinea fowls from backyard flocks from the same investigated area, the state of Rio de Janeiro, indicating that nematodes of this group are very common in domestic galliforms of this region. Nevertheless, the authors referred to lower values related to the prevalence and intensity of infection, that were of 5.5 and $10 \%$, repectively, for E. perforans and, conversely, higher for species of Capillaria in the inferior digestive tract, with $52.8 \%$ of prevalence and $57 \%$ of intensity of infection. In Denmark, Madsen (1941) verified a prevalence of $73 \%$ of another trichurid species, Capillaria contorta, parasitizing the crop and esophagus of ring-necked pheasants. Kellogg and Prestwood (1968) reported to a prevalence of 100\%, mean intensity of 27 and range of infection of 16-75 in the occurrence of $C$. phasianina in $P$. colchicus in the US; these values are higher than those presently referred. The trichurid B. obsignata is assignaled for the first time in Brazilian ring-necked pheasants.

The taxonomy of trichurid worms is complex, taking into account the lack of data and the morphological uniformity shared by the different species. Several authors consider incorrectly that all trichurids of birds may be identified to the genus Capillaria (Moravec et al. 1987, Barus \& Sergejeva 1989a). Trichurid infections in the crop and esophagus of domestic birds have been assigned to $C$. contorta when, in fact, are caused by E. perforans, often misidentified.

According to Barus and Sergejeva (1989b) and Moravec (1982) all the trichurid species parasitizing the anterior digestive tract of birds are allocated in the genus Eucoleus, including C. perforans and C. annulatus. The former authors also affirm that trichurids found in the anterior digestive tract of terrestrial birds and that have been identified to other species, including $C$. contorta, must be related to $E$. dispar, since $E$. contortus parasitizes aquatic birds.

Differently from the present investigation, previous reports refer to clinical signs, such as weakness, anorexia, emaciation, ruffled feathers, vomit, ataxy, diarrhoea, and death in galliforms, associated to infections with trichurid nematodes (Reis \& Nobrega 1938, Bickford \& Gaafar 1966, Hurst et al. 1979, Mathey \& Gutter 1979). Bickford and Gaafar (1966) referred to a morbity of over $20 \%$ in ringnecked pheasants infected with $C$. contorta, $C$. annulata, and $C$. caudinflata, not reporting, however, to the intensities of infection. The lack of clinical signs in the birds presently investigated may be related to the low worm burdens observed.

The gross and microscopic lesions associated to $E$. perforans indicate a low pathogenicity according to the intensities of infection registered. The alterations were, generally, similar to those reported by Reis and Nobrega (1938), Mathey and Gutter (1979), De Rosa and Shivaprasad (1999), and Menezes et al. (2001) in guinea fowls infected either with E. perforans or C. contorta, Singh et al. (1969) in domestic chickens with Capillaria sp., Bickford and Gaafar (1966) in ring-necked pheasants with C. contorta and C. annulata, Pizarro et al. (2000) in redlegged partridges (Alectoris rufa) infected with $C$. contorta.

Nevertheless, the lesions described by these authors were more severe. The gross lesions were represented by dilated crops, pseudo membranes, plaques, exudates, de- 

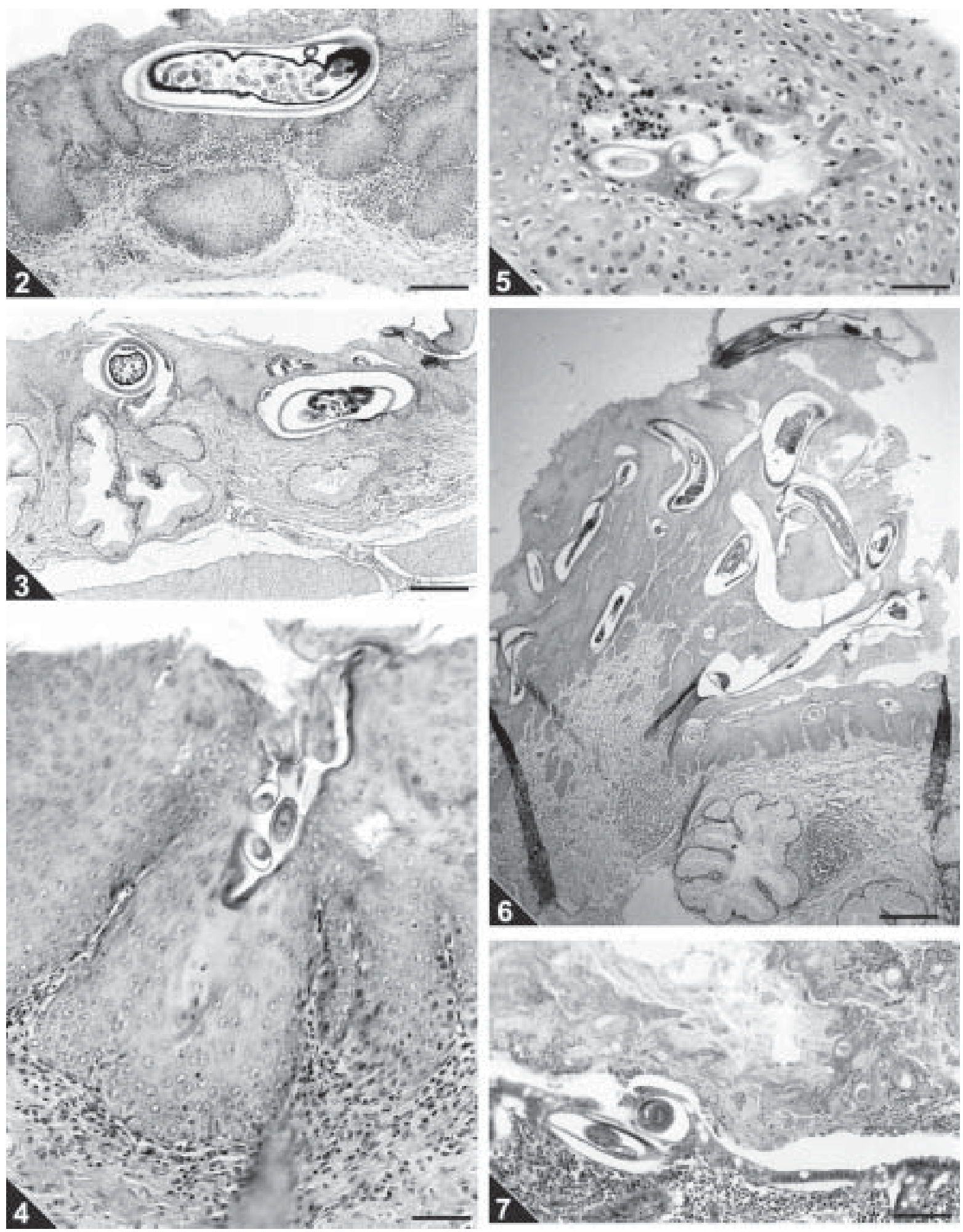

Fig. 2: cross-section of the crop of Phasianus colchicus showing sections of Eucoleus perforans deeply embedded in the stratified squamous epithelium and diffuse mixed inflammatory infiltrate in the lamina propria. HE. Bar $=0.05 \mathrm{~mm}$. Fig. 3: cross-section of the esophagus of $P$. colchicus showing specimens of E. perforans deeply embedded in the stratified squamous epithelium together with bioperculated acidophilic eggs in tunnels. The inflammatory reaction is absent. HE. Bar $=0.1 \mathrm{~mm}$. Fig. 4: cross-section of the crop of $P$. colchicus parasitized with E. perforans. Tunnel in the epithelium containing bioperculated acidophilic eggs projecting towards the lumen of the organ. HE. Bar $=0.05 \mathrm{~mm}$. Fig. 5: cross-section of the crop of P. colchicus parasitized with E. perforans. Tunnels in the epithelium lined with acidophilic material containing cellular debris around sections of bioperculate eggs. HE. Bar $=0.02 \mathrm{~mm}$. Fig. 6: cross-section of the esophagus of $P$. colchicus showing thickening and papillary transformation of the mucosa that has multiple sections of $E$. perforans. HE. Bar $=0.2 \mathrm{~mm}$. Fig. 7: cross-section of the caecum of $P$. colchicus showing sections of $C$. phasianina embedded in the mucosa together with an inflammatory infiltrate mainly mononuclear. HE. Bar $=0.1 \mathrm{~mm}$. 
tachable whitish masses covering the mucosa of the crop and esophagus and ulcerated areas; the microscopic alterations consisted of necrosis and sloughing of the epithelium, hiperkeratosis, severe flegmonous or fibrinosuppurative inflammation, bacterial colonies, epithelial spongiosis, hyperplasia of the esophageal mucous glands and epidermoid metaplasia, that were absent in the birds investigated herein.

Menezes et al. (2001) in guinea fowls (Numida meleagris) from the same region, and with lower burdens of $E$. perforans, observed that the esophagitis in these birds was very severe, suggesting that this host species is more susceptible to the infection than the ring-necked pheasants; this hypothesis is reinforced by Reis and Nobrega (1938), León and Soldevila (1978), Mathey and Gutter (1979), and De Rosa and Shivaprasad (1999). According to the latter authors, the cause of death of a vulture guinea fowl, parasitized with $C$. contorta could be related to undernourishment and severe emaciation followed by bacterial infection and septicemy. In fact, the tunnels derived from the migration of E. perforans in the epithelium of the upper digestive tract, are an entry for secondary infections caused by bacteria, fungi and possibly Trichomonas sp., that associated to this species of nematode, as reported by Reis and Nobrega (1938), cause severe lesions and death.

According to Kellogg and Prestwood (1968) in pheasants and in disagreement with Clapham (1949) in gray partidges (Perdix perdix), clinical signs and gross lesions were not observed in pheasants parasitized with $C$. phasianina. The microscopic lesions associated to this nematode and for the first time described in this host, were similar to the findings of Clapham (1949), although milder, without necrosis, fibrosis, eggs in the mucosa or sloughing of the epithelium. Despite the low pathogenicity associated to this parasite in the present study, probably on the basis of the low worm burdens, Clapham (1961) in England, observed fatal cases in ring-necked pheasants, demonstrating that this nematode is potentially pathogenic for these birds.

The absence of pathology associated to the parasitism by $B$. obsignata and E. annulatus was probably also related to the low intensities of infection observed. According to Jortner et al. (1967) the nematode B. obsignata in chickens, with burdens of over 30 worms, provokes epithelial desquamation, blunting and shortening of villi, and inflammation of lamina propria, probably resulting in decreased digestion and absorption. The nematode $E$. annulatus can be highly pathogenic for pheasants according to Cram (1936) and Bickford and Gaafar (1966).

\section{ACKNOWLEDGEMENTS}

To Bruno Eschenazi Silveira, Laboratório de Imagens, Instituto Oswaldo Cruz, Rio de Janeiro, for technical support with the figures.

\section{REFERENCES}

Amato JFR 1985. Manual de Técnicas para a Preparação de Coleções Zoológicas. 8. Platelmintos (Temnocefálidos, Trematódeos, Cestóides, Cestodários) e Acantocéfalos, Sociedade Brasileira de Parasitologia, São Paulo, 11 pp.

Barus V, Sergejeva TP 1989a. Capillariids parasitic in birds in the Palaearctic region. (1) Genus Capillaria. Acta Sc Nat Brno 23: 1-50.

Barus V, Sergejeva TP 1989b. Capillariidis parasitic in birds in the Palaearctic region. (2) Genera Eucoleus and Echinocoleus. Acta Sc Nat Brno 23: 1-47.

Behmer OA, Tolosa EMC, Freitas-Neto AG 1976. Manual de Técnicas para Histologia Normal e Patológica, EDART, São Paulo, 256 pp.

Bickford AA, Gaafar SM 1966. Multiple capillariasis in gamefarm pheasants. Avian Dis 10: 428-437.

Bush AO, Lafferty KD, Lotz JM, Shostak AW 1997. Parasitology meets ecology on its own terms: Margolis et al. revisited. J Parasitol 83: 575-583.

Clapham PA 1949. On Capillaria cadovulvata, pathogenic to Perdix perdix. J Helminthol 23: 69-70.

Clapham PA 1961. Recent observations on helminthiasis in some British game birds. J Helminthol (R.T. Leiper Suppl.): 35-40.

Costa HMA, Leite ACR, Guimarães MP, Lima WS 1986. Distribuição de helmintos parasitos de animais domésticos no Brasil. Arq Bras Med Vet Zootec 38: 465-579.

Cram EB 1936. Species of Capillaria parasitic in the upper digestive tract of birds. US Dept Agr Tech Bull 516: 1-27.

De Rosa M, Shivaprasad HL 1999. Capillariasis in a vulture guinea fowl. Avian Dis 43: 131-135.

Freitas JTF, Almeida JL 1935. Sobre os nematoda Capillarinae parasitas de esôfago e papo de aves. Mem Inst Oswaldo Cruz 30: 123-156.

Freitas JTF, Almeida JL 1936. O gênero Capillaria Zeder, 1800 (Nematoda, Trichuroidea) e as capilarioses nas aves domésticas. Rev Dep Nac Prod Anim 2: 311-316.

Freitas JTF, Mendonça JM, Guimarães JP 1959. Sobre algumas espécies do gênero Capillaria Zeder, 1800 parasitas de aves (Nematoda, Trichuroidea). Mem Inst Oswaldo Cruz 57: 1731.

Hurst GA, Turner LW, Tucker FS 1979. Capillariasis in penned wild turkeys. J Wildl Dis 8: 395-397.

Jortner BS, Helmboldt CF, Pirozok RP 1967. Small intestinal histopathology of spontaneous capillariasis in the domestic fowl. Avian Dis 11: 154-169.

Kellogg FE, Prestwood AK 1968. Case report and differentiating characteristics of Capillaria phasianina from pen-raised pheasants of Maryland. Avian Dis 12: 518-522.

León D, Soldevila M 1978. Capillaria annulata and Heterakis gallinarum infections in guinea fowl in Puerto Rico - A case report. J Agric Univ Puerto Rico 62: 428-430.

Madsen H 1941. The occurrence of helminths and coccidia in partridges and pheasants in Denmark. J Parasitol 27: 2934.

Madsen H 1951. Notes on the species of Capillaria Zeder, 1800 known from gallinaceous birds. J Parasitol 37: 257265.

Mathey WJ, Gutter AE 1979. Capillaria perforans Kotlan and Orosz 1931 in vulturine guinea fowl. Poult Sci 58: 1083.

Menezes RC, Mattos Júnior DG, Tortelly R 2001. Freqüência e patologia das infecções causadas por nematóides e cestóides em galinhas-d'angola (Numida meleagris Linnaeus, 1758) criadas extensivamente no estado do Rio de Janeiro, Brasil. Rev Bras Cienc Vet 8: 35-39.

Millán J, Gortázar G, Tizzani P, Buenestado FJ 2002. Do helminths increase the vulnerability of released pheasants to fox predation? J Helminthol 76: 225-229.

Moravec F 1982. Proposal of a new systematic arrangement of nematodes of the family Capillariidae. Folia Parasitol 29: 119-132.

Moravec F, Prokopic J, Shlikas AV 1987. The biology of nematodes of the family Capillariidae Neveu-Lemaire, 1936. Folia 
Parasitol 34: 39-56.

Permin A, Bisgaard M, Frandsen F, Pearman M, Kold J, Nansen $P$ 1999. Prevalence of gastrointestinal helminths in different poultry production systems. Br Poult Sci 40: 439-443.

Pizarro M, Villegas P, Rodriguez A, Gonzalez M, Flores JM 2000. Capillaria contorta parasitism in red-legged partridge under farm conditions in Spain: histopathology of the upper digestive system. Worlds Poult Sci J 56: 159-166.

Reis J, Nobrega P 1938. Sobre as lesões produzidas pela Capillaria perforans Kotlán e Orosz nas aves domésticas. Arq Inst Biol 9: 21-23.

Ruff MD 1999. Important parasites in poultry production sys- tems. Vet Parasitol 84: 337-347.

Silva LFW 1987. Criação de Faisões, Nobel, São Paulo, 64 pp. Singh R, Sharma RM, Sah RL 1969. Parasitic ingluvitis (Capillaria sp.) in domestic fowl. Indian Vet J 46: 947-948.

Vicente JJ, Rodrigues HO, Gomes DC, Pinto RM 1995. Nematóides do Brasil. Parte IV: Nematóides de aves. Rev Bras Zool 12: 1-273.

Zander DV, Bermudez AJ, Mallinson ET 1997. Principles of disease prevention: diagnosis and control. In BW Calnek, HJ Barnes, CW Beard, LR McDougald, YM Saif (eds), Diseases of Poultry, 10 th ed., Iowa State University Press, Ames, p. 3-45. 